\title{
PERAN CAREGIVER MENGEMBANGKAN KEMANDIRIAN HYGIENE ANAK BINAAN DI YAYASAN SOSIAL KOTA TARAKAN
}

\author{
Nurman Hidaya $^{1)}$, Siti Ruqiah ${ }^{2)}$ \\ 1\&2Prodi DIII Keperawatan Universitas Borneo Tarakan \\ *Email : nurmanhidaya@borneo.ac.id
}

\begin{abstract}
Abstrak
Kemampuan mandiri dalam hygiene merupakan faktor terpenting dalam mencegah covid-19. Untuk memahami strategi dan tindakan caregiver dalam mengembangkan kemandirian hygiene anak panti sosial. Penelitian kualitatif dengan desain fenomenologi yang melibatkan tujuh orang caregiver. Pengumpulan data dilakukan dengan cara wawancara mendalam, menggunakan tematik Braun \& Clarke dilakukan untuk menganalisis data. Hasil penelitian ini menemukan lima tema yang menggambarkan pengalaman caregiver dalam mengembangkan kemandirian hygiene anak saat pembatasan sosial skala besar meliputi : mewajibkan anak-anak waktu masuk panti setelah dari luar untuk mencuci tangan, menjadi role model dalam menerapkan protokol kesehatan, Sosialisasi cara mencuci tangan yang baik, sosialisasi menjaga daya tahan tubuh, bersabar dalam mengajarkan dan mengingatkan. berusaha secara maksimal dalam meningkatkan kemandirian hygiene anak.
\end{abstract}

Kata Kunci : Pengasuh, kebersihan diri dan anak.

\begin{abstract}
The Role of Caregivers in Developing Hygiene Self-Reliance for Fostered Children at Tarakan City Social Foundation. Independent ability in terms of hygiene is an important factor to prevent Covid 19. To understand the caregiver's strategies and actions in developing the independent hygiene of orphanage children. Phenomenological qualitative research design involving seven people caregivers. Data was collected by in depth interviews, data analysis using thematic Braun \& Clark. The results of this study found five themes that describe the care giver's experience in developing children's hygiene independence when large-scale social restrictions include: requiring children to enter the nursing home after washing their hands from outside, being a role model in implementing health protocols, and socializing how to wash their hands. well, socialization to maintain endurance, be patient in teaching and reminding. strive to the maximum in improving the independence of children's hygiene.
\end{abstract}

Keywords: Caregiver, Hygiene and Child. 


\section{Pendahuluan}

Kemampuan mandiri dalam hygiene merupakan faktor terpenting dalam mencegah covid 19. Kemandirian adalah kemampuan dalam menyelesaikan tugas tanpa mengandalkan orang lain yang diaplikasikan melalui sikap dan perilaku (Mustari, 2014). pendapat diatasa juga didukung oleh Wiyani (2013) yang menyatakan bahwa anak yang mandiri dapat dihasilkan dari suatu keadaan yang terjadi dengan sendirinya yang pada akhirnya membentuk karakter anak tersebut untuk tidak mudah bergantung pada orang lain (Kumayang Sari, Kurniah dan Anni Suprapti, 2016). Terdapat beberapa faktor yang mempengaruhi kemandirian anak.

Kemandirian anak berkembang dengan dipengaruhi oleh 2 faktor yaitu : 1). Faktor internal dan 2) faktor eksternal. Untuk faktor internal terdiri dari kondisi fisiologis dan kondisi psikologis. Sedangkan faktor eksternal meliputi : lingkungan, rasa cinta dan kasih sayang, pola asuh orang tua dalam keluarga dan pengalaman dalam kehidupan. Kemandirian anak sejak usia dini sangat penting untuk dikembangkan karena bekal kemandirian yang mereka dapatkan ketika kecil akan membentuk mereka menjadi pribadi yang mandiri, cerdas, kuat, dan percaya diri ketika menginjak dewasa nanti, sehingga mereka akan siap menghadapi masa depan yang baik (Wiyani, 2013). Anak yang belum mampu untuk mandiri akan mengalami beberapa hambatan atau masalah

Beberapa masalah yang sering dijumpai pada anak yang belum bisa mandiri meliputi : Seringkali kita jumpai anak sudah beranjak usia 7 tahun masih selalu minta 'dikelonin' saat akan tidur, bahkan ingin selalu tidur bersama orang tuanya atau harus selalu menyuapi setiap kali mau makan, memandikannya, 'mencebokinya' padahal usianya sudah besar. Karena anak tidak pernah dilatih dan dibiasakan sejak dini untuk hidup mandiri, sampai dewasa pun kadang masih manja (Purwanto, 2009). Ketidakmampuan anak mandiri terutama untuk hygiene diri dapat menyebabkan anak mudah mengalami gangguan kesehatan..

Saat ini di Indonesia sedang mengalami pandemi virus Covid-19, dimana masingmasing individu harus mampu menjaga kebersihan diri dan lingkungan supaya dapat terhindar dari virus tersebut. Di Indonesia jumlah penderita Covid-19 terus meningkat yang membuat pemerintah memberlakukan sistem social distancing dan physical distancing bahkan pemerintah juga sudah memberlakukan sistem kerja dirumah (work from home) dan merubah sistem belajar dari sekolah menjadi belajar di rumah. Semua itu diterapkan sebagai usaha pencegahan penularan covid-19 di kalangan anak-anak, 
oleh karena itu sistem belajar anak dialihkan dirumah dengan pengawasan maksimum oleh orang tua.

Untuk anak yang mendapatkan pendidikan di panti asuhan / yayasan sosial pengawasan diberikan kepada orang tua asuh/ caregiver. Peran caregiver di tengah pandemi covid-19 menjadi lebih besar, dimana usia anak-anak suka berinteraksi, bermain sambil belajar dan akan menjadi beban tambahan bagi caregiver dalam mengawasi banyak anak di panti asuhan. Anak yang sudah bisa mandiri dalam hal hygiene potensi untuk tertular covid19 lebih kecil dibandingkan dengan anak yang hygiene diri masih dibantu dan diingatkan oleh orang tua asuh/ care giver. Untuk daerah yang memiliki resiko tinggi penularan yang ditandai dengan pertambahan yang signifikan jumlah pasien penderita covid-19 pemerintah daerah harus menerapkan PSBB dengan persetujuan Menteri Kesehatan.

Tarakan merupakan salah satu daerah yang menerapkan PSBB dengan landasan Keputusan Menkes No HK.01.07/MENKES/ 261/2020 Tentang kriteria pemberlakuan PSBB di Kota Tarakan Provinsi Kalimantan Utara. Dengan ditetapkannya PSBB di Kota Tarakan menandakan bahwasanya telah terjadi peningkatan penderita covid 19.

Berdasarkan penjelasan diatas peneliti tertarik untuk meneliti Pengalaman caregiver Mengembangkan Kemampuan dan
Kemandirian Hygiene Anak Binaan di Yayasan Sosial Al-Marhamah Tarakan Saat Pembatasan Sosial Berskala Besar.

\section{Metode}

Menggunakan metode penelitian kualitatif dengan desain fenomenologi. Caregiver yang bekerja di yayasan sosial/ panti asuhan. pemilihan partisipan dalam dilakukan dengan menggunakan teknik purposive sampling dan harus memenuhi kriteria inklusi serta berada di tempat penelitian, hal ini dilakukan supaya saat pengambilan data partisipan tidak merasa canggung sehingga lebih mendalam informasi yang didapatkan. kriteria inklusi yang dijadikan partisipan dalam penelitian ini adalah: (1) caregiver yang bekerja di yayasan sosial / panti asuhan (2) caregiver yang memiliki pengalaman merawat anak di yayasan sosial / panti asuhan (3) sehat fisik, (5) menandatangani surat kesediaan sebagai partisipan. Sebanyak 7 orang caregiver yang menjadi partisipan dalam penelitian ini yang dilakukan periode september-oktober 2020. Proses seleksi terhadap partisipan diawali dengan peneliti mengajukan izin penelitian kemudian menjelaskan tujuan dari penelitian serta kriteria partisipan yang dijadikan objek penelitian. Pengumpulan data dimulai dari caregiver pertama selanjutnya dikembangkan ke partisipan lainnya. Pada penelitian ini, 
saturasi data dicapai pada wawancara partisipan ke tujuh.

Data dikumpulkan melalui wawancara mendalam (Indepth interview) dengan pertanyaan terbuka dan dikembangkan oleh peneliti. Analisis data dilakukan dengan menggunakan Analisis tematik Braun \& Clarke. Penelitian ini telah mendapatkan layak etik di Universitas Borneo Tarakan.

\section{Hasil dan Pembahasan}

Hasil penelitian ditemukan 5 tema yang menggambarkan pengalaman caregiver dalam mengembangkan kemandirian hygiene anak untuk mencegah penularan covid-19 saat pembatasan sosial skala besar meliputi : mewajibkan anak-anak waktu masuk panti setelah dari luar untuk mencuci tangan, menjadi role model dalam menerapkan protokol kesehatan, Sosialisasi cara mencuci tangan yang baik, sosialisasi menjaga daya tahan tubuh, Bersabar dalam mengajarkan dan mengingatkan

\section{Mewajibkan anak untuk mencuci tangan}

Kondisi pandemic covid 19 yang masih berlanjut membuat beberapa sekolah dan pendidikan formal secara luring ditiadakan dan diganti dengan pembelajaran daring. Tetapi beda hal dengan pembelajaran di tempat tidak formal seperti pembelajaran yang dilakukan di panti sosial, waktu awal pandemi covid-19 pembelajaran dihentikan tetapi setelah kasus covid-19 di Tarakan berkurang maka pembelajaran pun dibuka kembali tetapi mengurangi beberapa kegiatan karena harus dengan memperhatikan standar protokol kesehatan. Penerapan standar kesehatan dijalankan dengan ketat salah satu yang diwajibkan kepada anak binaan yaitu mencuci tangan. Pernyataan tersebut sesuai dengan wawancara peneliti lakukan kepada beberapa anak binaan yang menyatakan saat pembelajaran berlangsung dan saat mereka dari luar kembali ke panti anak-anak diwajibkan untuk melakukan cuci tangan terlebih dahulu.

Kementerian Kesehatan RI telah mengeluarkan banyak informasi-informasi aktual dan panduan-panduan terkait Covid19, tetapi berita-berita tidak sahih masih banyak terjadi dan simpang siur yang tersebar di antara masyarakat. Padahal penularan virus ini dapat dicegah dengan menerapkan Perilaku Hidup Bersih dan Sehat (PHBS), seperti cuci tangan dengan baik dan benar, etika batuk, serta menjaga kesehatan dan sistem kekebalan tubuh.

Menurut Darmalaksana, Hambali dan Masrur (2020) anak yang menerapkan pola hidup bersih dan sehat telah menjaga dirinya dan lingkungan dari penyebaran Covid-19. Dengan digalakkannya PHBS pada anak salah satunya melalui cuci tangan menggunakan 
sabun dapat mencegah penularan covid-19. Pendapat diatas sesuai dengan penelitian Tabi'in, A (2020) yang menyatakan salah satu pencegahan penularan covid-19 dengan mencuci tangan dengan sabun.

\section{Menjadi role model dalam menerapkan protokol kesehatan}

Pada masa pandemic covid 19 yang masih berlanjut membuat beberapa pembelajaran yang dilakukan di panti sosial pada awal pandemi covid-19 dihentikan tetapi setelah kasus covid-19 di Tarakan berkurang maka pembelajaran pun dibuka kembali tetapi mengurangi beberapa kegiatan karena harus dengan memperhatikan Standar protokol kesehatan. Hasil wawancara dengan caregiver didapatkan bahwasanya untuk menerapkan standar kesehatan pada anak maka mereka menjadi contoh (role model) pada anak untuk menerapkan standar tersebut. Pernyataan caregiver tersebut sejalan dengan pernyataan dari anak binaan yang menyatakan bahwa sebelum masuk ruangan guru selalu melakukan cuci tangan yang diikuti oleh murid serta guru selalu memakai masker.

Keberhasilan didalam didalam mendidik anak juga ditentukan oleh menjadikan diri sebagai role model pada anak, karena guru (pendidik) merupakan contoh yang menjadi panutan dan diikuti oleh anak. Hasil peneliti Rosidin, Sumarna, dan Eriyani (2019) menunjukkan bahwa peran tokoh masyarakat sangat dominan dalam pembentukan dan pelaksanaan kebiasaan menerapkan hidup bersih dan sehat.

\section{Sosialisasi cara mencuci tangan}

Hasil wawancara peneliti dengan dengan caregiver didapatkan, sebagai care giver menyatakan bahwa sebagai sebagai pengasuh dan pendidik anak terutama dalam masa pandemi covid-19 meningkatkan kemandirian hygiene anak yang baik dan benar maka salah satunya dengan melakukan sosialisasi cara mencuci tangan sesuai dengan panduan Kemenkes dalam rangka untuk mencegah penularan covid-19.

Hal tersebut sejalan dengan UndangUndang Nomor 36 Tahun 2009 Pasal 79 tentang Kesehatan, ditegaskan bahwa "Kesehatan Sekolah" diselenggarakan untuk meningkatkan kemampuan hidup sehat peserta didik dalam lingkungan hidup sehat sehingga dapat belajar, tumbuh, berkembang secara harmonis sehingga diharapkan menjadi sumber daya manusia yang berkualitas (Taryatman, 2016).

\section{Sosialisasi Menjaga Daya Tahan Tubuh}

Hasil wawancara peneliti dengan dengan caregiver didapatkan, sebagian besar caregiver menyatakan bahwa telah melakukan sosialisasi kepada anak binaan tentang menjaga daya tahan tubuh anak diantaranya dengan menjaga kesehatan, kebersihan, dan olahraga. Hasil 
wawancara peneliti dengan anak binaan didapatkan anak menyatakan bahwa bapak dan ibu guru telah menyampaikan tentang tata cara menjaga daya tahan tubuh yang telah disampaikan oleh guru dan mereka juga difasilitasi untuk konsumsi makanan yang bergizi seperti daging dan susu, diajarkan cara menjaga kebersihan diri dan lingkungan serta melakukan difasilitasi dalam melakukan olahraga seperti senam pagi pada hari jum'at.

Hal tersebut sejalan dengan Tabiin, A (2020) yang menyatakan bahwa Penyuluhan (sosialisasi) dan pemberian makanan sehat yang mengandung gizi dan zat yang dibutuhkan oleh tubuh dapat meningkatkan imun anak. Komposisi gizi berupa karbohidrat, lemak, protein, vitamin, mineral, dan air. Makanan yang sehat ini akan memberikan daya tahan tubuh yang baik untuk anak-anak dan berimplikasi pada perkembangan anak yang optimal.

Beberapa hal penting dapat dilakukan oleh guru untuk muridnya diantaranya menjaga kesehatan anak didik, sesuai dengan amanat Undang-undang Nomor 36 Tahun 2009 Pasal 79 tentang Kesehatan, ditegaskan bahwa "Kesehatan Sekolah" dan diselenggarakan untuk meningkatkan kemampuan hidup sehat peserta didik dalam lingkungan hidup sehat sehingga dapat belajar, tumbuh, berkembang secara harmonis sehingga diharapkan menjadi sumber daya manusia yang berkualitas (Taryatman, 2016).

\section{Bersabar dalam mengajarkan dan mengingatkan}

Untuk meningkatkan kemandirian dan kesadaran anak binaan dalam menjaga higiene diri memang tidak mudah, sebagian besar caregiver menyatakan bahwa anak-anak terkadang lupa didalam melakukan cuci tangan saat masuk dari luar dan masuk ke lingkungan panti. Disini peran caregiver untuk selalu mengingatkan anak dan memberikan contoh supaya selalu menjaga kebersihan diri selain itu di usia anak-anak memang lagi suka bermain terkadang karena keasyikan bermain maka lupa untuk cuci tangan dan menjaga jarak dengan teman sebaya walaupun hal tersebut sudah sering diingatkan. Oleh karena itu kesabaran merupakan hal terpenting dalam memberikan pembelajaran kepada anak,

\section{Kesimpulan}

Ditemukan 5 tema dalam penelitian ini yang menggambarkan pengalaman caregiver dalam mengembangkan kemandirian hygiene anak untuk mencegah penularan covid-19 saat pembatasan sosial skala besar meliputi : mewajibkan anak-anak waktu masuk panti setelah dari luar untuk mencuci tangan, menjadi role model dalam menerapkan protokol kesehatan, sosialisasi cara mencuci tangan yang baik, sosialisasi menjaga daya 
tahan tubuh, bersabar dalam mengajarkan dan mengingatkan.

\section{Referensi}

Afriyeni, N., \& Sartana, S. (2017). Gambaran Tekanan Dan Beban Yang Dialami Oleh Keluarga Sebagai Caregiver Penderita Psikotik Di Rsj Prof. H.B. Sa'Anin Padang. Jurnal Ecopsy, 3(3), 115-120. https://doi.org/10.20527/ecopsy.v3i3.267 1

Darmalaksana, Wahyudin, R Yuli Ahmad Hambali, and Ali Masrur.2020. "Analisis Pembelajaran Online Masa WFH Pandemic Movie-19 sebagai Tantangan Pemimpin Digital Abad 2," 12.

Kemenkes RI. (2020b). Pedoman Pencegahan dan Pengendalian Coronavirus Disease (COVID-19). Pedoman Kesiapan Menghadapi COVID-19.

Kumayang Sari, A., Kurniah dan Anni Suprapti, N., Kurniah, N., \& Suprapti, A. (2016). Upaya Guru Untuk Mengembangkan Kemandirian Anak Usia Dini Di Gugus Hiporbia. Jurnal Ilmiah Potensia, 1(1), 1-6.

Mubarok, Z., Hafidhuddin, D., Tanjung, H., \& Tamam, M. (2018). Pendidikan wirausaha bagi anak Panti Asuhan Yatim Muhammadiyah dan pengaruhnya terhadap kemandirian anak. Jurnal Pendidikan Islam Ta'dinb, 7(2), 152172. https://doi.org/10.32832/tadibuna.v7i2.1 $\underline{359 .}$.

Muntaha, 2012. Pendidikan Kemandirian Anak-Anak Yatim Piatu Panti Asuhan Darul Hadlanah Blotongan Salatiga. Skripsi tidak dipublikasikan. Salatiga : Jurusan Tarbiyah STAIN Salatiga.

Mustari, Mohamad. (2014). Nilai Karakter Refleksi Untuk Pendidikan. Jakarta: PT RajaGrafindo Persada.

Purwanto. (2009). Upaya guru untuk melatih kemandirian anak usia dini di TK islam Ar-rahman Papringan Yogyakarta. Skripsi. Yogyakarta. Universitas Islam Negeri Sunan Kalijaga.

Rosidin, U., Sumarna, U., dan Eriyani, T. (2019). Determinan Pelaksanaan PHBS Rumah Tangga di Desa Jayaraga Tarogong Kidul Kabupaten Garut. Jurnal Keperawatan BSI, $7(1)$.

Tabi'in, A. (2020). Perilaku Hidup Bersih Dan Sehat (PHBS) Pada Anak Usia Dini Sebagai Upaya Pencegahan Covid 19. JEA (Jurnal Edukasi AUD), 6(1), 58. https://doi.org/10.18592/jea.v6i1.3620

Taryatman. (2016). Budaya Hidup Bersih dan Sehat di Sekolah Dasar Untuk Membangun Genersi Muda yang Berkarakter. Trihayu: Jurnal Pendidikan, 3(1), 8-13.

Undang-Undang Nomor 36 Tahun 2009 pasal 79 tentang Kesehatan.

Wiyani, Novan Ardy. 2013. Bina Karakter Anak Usia Dini. Jogjakarta: ArRuzz Media. 